\title{
Geophysical constraints on the properties of a subglacial lake in northwest Greenland
}

\author{
Ross Maguire $^{1,2}$, Nicholas Schmerr ${ }^{1}$, Erin Pettit ${ }^{3}$, Kiya Riverman $^{4}$, Christyna Gardner $^{5}$, Daniella N. DellaGiustina ${ }^{6}$, \\ Brad Avenson $^{7}$, Natalie Wagner ${ }^{8}$, Angela G. Marusiak ${ }^{1}$, Namrah Habib ${ }^{6}$, Juliette I. Broadbeck ${ }^{6}$, Veronica J. Bray ${ }^{6}$, \\ and Samuel H. Bailey ${ }^{6}$ \\ ${ }^{1}$ Department of Geology, University of Maryland, College Park, MD 20742, USA \\ ${ }^{2}$ Department of Earth and Planetary Sciences, University of New Mexico, Albuquerque, NM 87131, USA \\ ${ }^{3}$ College of Earth, Ocean, and Atmospheric Sciences, Oregon State University, Corvallis, OR 97331-5503, USA \\ ${ }^{4}$ Courant Institute of Mathematical Sciences, New York University, New York, NY 10012 USA \\ ${ }^{5}$ Department of Geosciences, Utah State University, Logan, UT 84322-4505, USA \\ ${ }^{6}$ Lunar and Planetary Laboratory, University of Arizona, Tucson, AZ 85721-0092, USA \\ ${ }^{7}$ Silicon Audio Inc., Austin, Pflugerville, TX 78660, USA \\ ${ }^{8}$ Department of Geosciences, University of Alaska, Fairbanks, AK 99775, USA
}

Correspondence: Ross Maguire (rmaguire@umd.edu)

Received: 30 October 2020 - Discussion started: 13 November 2020

Revised: 10 May 2021 - Accepted: 11 May 2021 - Published: 16 July 2021

\begin{abstract}
In this study, we report the results of an activesource seismology and ground-penetrating radar survey performed in northwestern Greenland at a site where the presence of a subglacial lake beneath the accumulation area has previously been proposed. Both seismic and radar results show a flat reflector approximately $830-845 \mathrm{~m}$ below the surface, with a seismic reflection coefficient of $-0.43 \pm 0.17$, which is consistent with the acoustic impedance contrast between a layer of water and glacial ice. Additionally, in the seismic data we observe an intermittent lake bottom reflection arriving between $14-20 \mathrm{~ms}$ after the lake top reflection, corresponding to a lake depth of approximately $10-15 \mathrm{~m}$. A strong coda following the lake top and lake bottom reflections is consistent with a package of lake bottom sediments although its thickness and material properties are uncertain. Finally, we use these results to conduct a first-order assessment of the lake origins using a one-dimensional thermal model and hydropotential modeling based on published surface and bed topography. Using these analyses, we narrow the lake origin hypotheses to either anomalously high geothermal flux or hypersalinity due to local ancient evaporite. Because the origins are still unclear, this site provides an intriguing opportunity for the first in situ sampling of a subglacial lake in Greenland, which could better constrain
\end{abstract}

mechanisms of subglacial lake formation, evolution, and relative importance to glacial hydrology.

\section{Introduction}

There is mounting evidence that subglacial lake systems below the Antarctic and Greenland ice sheets play an important role in glacier dynamics and ice-sheet mass balance considerations. In Antarctica, the presence of subglacial lakes is suspected to promote ice flow by reducing basal shear stress (e.g., Bell et al., 2007), and periodic drainage events have been linked to accelerated ice flow in outlet glaciers and ice streams (e.g., Stearns et al., 2008; Siegfried et al., 2016). Similarly, in Greenland subglacial lake systems also provide a reservoir for the storage of surface or basal meltwater and hence may be an important, but largely unknown, factor in global sea level change. Additionally, subglacial lakes are of interest due to their ability to harbor complex microorganisms adapted to extreme environments (Achberger et al., 2016; Campen et al., 2019; Vick-Majors et al., 2016) and paleoenvironmental information contained in subglacial lake sediments (Bentley et al., 2011). 
While the presence and nature of subglacial lakes underlying the Antarctic ice sheet has been studied for more than 50 years, the existence of subglacial lakes below the Greenland ice sheet is a relatively recent discovery and comparatively little is known about their properties and origin. Detection of subglacial lakes has relied on a variety of methods, including radio-echo sounding (Robin et al., 1970; Siegert et al., 1996; Langley et al., 2011; Palmer et al., 2013; Young et al., 2016; Bowling et al., 2019), satellite altimetry measurements (Fricker et al., 2007; Palmer et al., 2015; Siegfried and Fricker, 2018; Willis et al., 2015), and active-source seismic experiments (e.g., Horgan et al., 2012; Peters et al., 2008). Using these techniques, approximately 400 subglacial lakes have been detected in Antarctica (Wright and Siegert, 2012), of which 124 are considered "active" by Smith et al. (2009). In Greenland, subglacial lakes were first detected in radioecho sounding data by Palmer et al. (2013), who identified two small (roughly $10 \mathrm{~km}^{2}$ ) flat regions of anomalously high basal reflectivity below the northwestern Greenland ice sheet. These features, named L1 and L2, were discovered below 757 and $809 \mathrm{~m}$ of ice, respectively. Recently, Bowling et al. (2019) greatly expanded the inventory of subglacial lakes in Greenland to approximately 54 candidates based on a combination of airborne radio-echo sounding and satellite altimetry data. The new inventory shows that, in contrast to subglacial lakes in Antarctica which tend to form under thick ( $>4 \mathrm{~km})$ warm-based ice in the continental interior, the majority of subglacial lakes in Greenland are found under relatively thin $(1-2 \mathrm{~km})$ ice near the margins of the ice sheet. Bowling et al. (2019) find that most subglacial lakes in Greenland appear to be stable features, showing temporally consistent radio-echo sounding signatures and an absence of vertical surface deformation over the decadal timescales of observation. Of the 54 candidate lakes, only 2 showed signs of vertical surface deformation indicative of active draining or recharge.

The formation and location of the detected subglacial lake features in Greenland remains elusive because many are located in regions where observations and modeling suggest that the base of the ice is frozen to its bed (MacGregor et al., 2016). Complicating our understanding of the nature of subglacial lakes is the fact that uniquely identifying lakes in radar data is challenging since basal reflectivity is sensitive to both the physical properties and the roughness of the material underlying the ice (e.g., Jordan et al., 2017). Amplitude anomalies of radar echoes in the range of +10 to $+20 \mathrm{~dB}$ are often interpreted as subglacial lakes, although flat regions of saturated sediment may produce similar anomalies. Furthermore, the total volume of water stored in subglacial lake systems is unknown since airborne and space-based remote sensing observations are incapable of measuring lake depth (i.e., water column thickness).

Seismic investigations provide an independent means of confirming the presence of subglacial lakes and are capable of measuring lake depth and underlying geological structures which can provide valuable clues to their formation and total volume. For example, Peters et al. (2008) performed an active-source seismic survey near the South Pole region of Antarctica and observed reflections from both the top and bottom of a subglacial lake that lies $2.8 \mathrm{~km}$ below the ice surface, which allowed them to image a lake depth of about $32 \mathrm{~m}$ and infer the underlying sedimentary structure. Additionally, Woodward et al. (2010) performed an active-source seismic investigation of Lake Ellsworth in west Antarctica, which lies at the bottom of a narrow subglacial valley below approximately $3 \mathrm{~km}$ of ice. They found large variations in lake depth from between 52 and $156 \mathrm{~m}$ and were able to estimate the total volume of liquid water to be $1.37 \mathrm{~km}^{3}$. Later, Smith et al. (2018) reanalyzed the data to investigate the sedimentary structure below Lake Ellsworth and found evidence of a thin sedimentary package (minimum thickness of $6 \mathrm{~m}$ ), which they suggest may have built up slowly over at least $150 \mathrm{kyr}$. This contrasts to results from seismic investigations of Lake Vostok, the largest of Antarctica's subglacial lakes, which show evidence for a much thicker water column (up to $1100 \mathrm{~m}$ ) and a thicker layer of lake bottom sediments (up to $400 \mathrm{~m}$ ) below approximately $4 \mathrm{~km}$ of ice (e.g., Filina et al., 2008). Seismic investigations have also been useful for illuminating the properties of subglacial lakes below much thinner ice columns in active ice streams, such as the subglacial Lake Whillans which is situated below approximately $800 \mathrm{~m}$ of ice and has a maximum water column thickness of less than $10 \mathrm{~m}$ (e.g., Horgan et al., 2012).

\section{Methods}

\subsection{Field experiment}

In June 2018, we conducted a geophysical survey in northwestern Greenland above the candidate subglacial lake feature named L2 by Palmer et al. (2013). This feature sits within a $980 \mathrm{~km}^{2}$ drainage basin, is roughly adjacent $(<10 \mathrm{~km})$ to the nearest ice divide (Fig. 1a and b), and is within an accumulation area. Using RACMO2 $1 \mathrm{~km}$ resolution modeling of Greenland's near-surface climate and surface mass balance (Noël et al., 2018), we estimate the mean annual air temperature to be $-22^{\circ} \mathrm{C}$. This model is forced with ERA-Interim reanalysis climate information (Dee et al., 2011) at the boundaries and evaluated with in situ observations. The mean annual snow accumulation rate at the field site is $\sim 0.3 \mathrm{~m} \mathrm{yr}^{-1}$ ice equivalent. In order to confirm the presence of the subglacial lake and investigate its physical properties, we collected data using both active-source seismology and ground-penetrating radio-echo sounding (GPR).

The active-source seismic experiment (Fig. 1c) consisted of a moving line of twenty-four $40 \mathrm{~Hz}$ vertical component geophones spaced $5 \mathrm{~m}$ apart. For each line, we collected data at four shot locations using an $8 \mathrm{~kg}$ sledgehammer impacted against a $1.5 \mathrm{~cm}$ thick steel plate. At each source location 
(a)

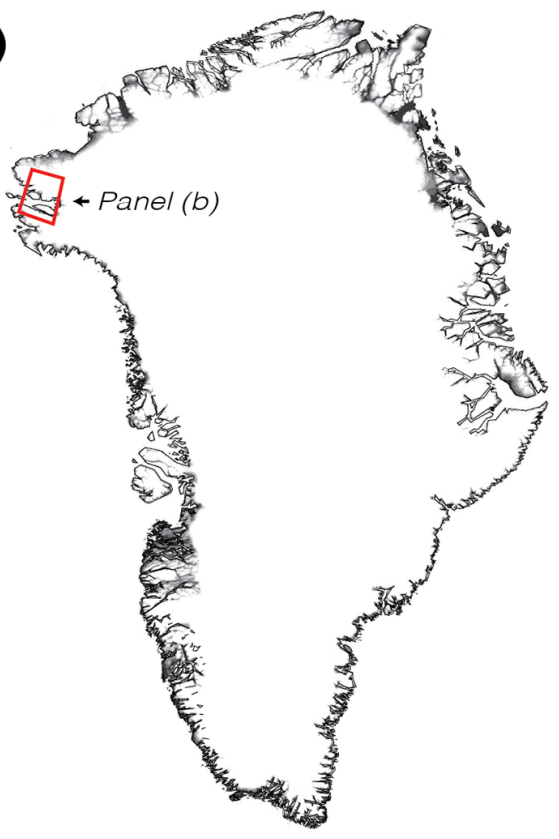

(c)

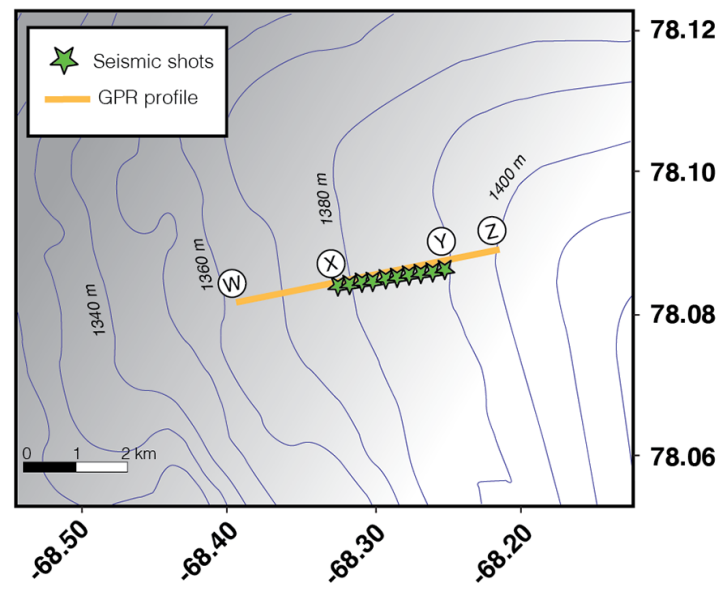

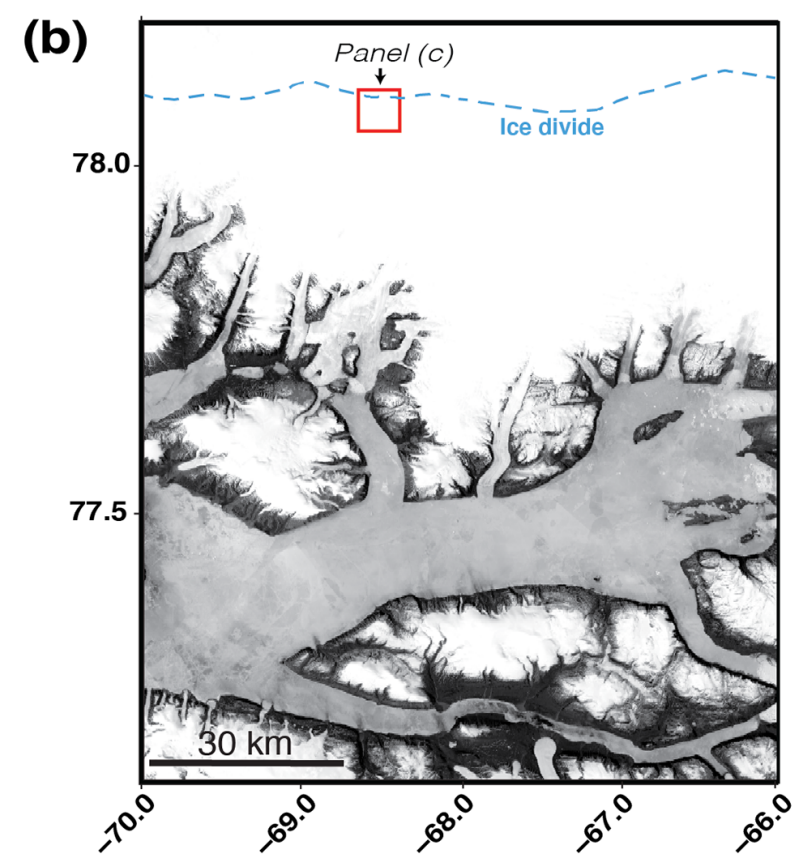

(d)

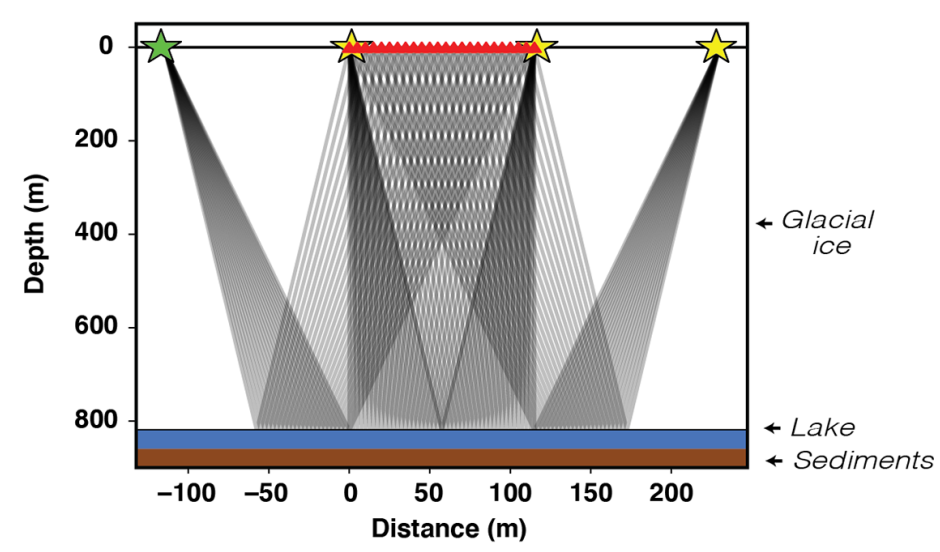

Figure 1. (a) Map of Greenland showing our field location in the northwest. (b) Composite satellite image from Landsat 8 taken between 20 May 2018 and 27 May 2018. (c) Close-up map of field region. The green stars show the active-source shot, and the orange line shows the track of the GPR survey. Only the first of four shot locations for each geophone line is plotted. (d) Geometry of the active-source experiment for a single geophone line. The black lines indicate the raypaths of R1 between all source locations (stars) and geophones (red triangles).

at least five hammer shots were stacked into a single shot gather in order to increase the signal-to-noise ratio. The first shot location of each line was offset $115 \mathrm{~m}$ from the first geophone, and subsequent shot locations were moved $115 \mathrm{~m}$ along the line. After data were collected for each of the four shot locations, the line was moved $230 \mathrm{~m}$ east along the traverse and data collection was repeated. The seismic line was moved a total of 10 times, totalling 40 separate shot locations. Using this geometry, we obtained reflection points at the ice bottom spaced every $2.5 \mathrm{~m}$ along a traverse totalling $2400 \mathrm{~m}$ (Fig. 1d). We created a seismic reflection image by bandpass-filtering data between $100-200 \mathrm{~Hz}$ and ap- plying a normal moveout (NMO) correction with a velocity of $3700 \mathrm{~m} \mathrm{~s}^{-1}$, which was found to be the average velocity of the ice column from NMO analysis of the primary bed reflection. High-frequency spatial noise with wavenumbers greater than $0.05 \mathrm{~m}^{-1}$ was removed with $\mathrm{f}-\mathrm{k}$ filtering. Shot gathers with offsets of -115 and $230 \mathrm{~m}$ from the first geophone contained an air wave arrival that was muted by zeroing a $10 \mathrm{~ms}$ window with a moveout of $315 \mathrm{~m} \mathrm{~s}^{-1}$.

The GPR data were collected across a $\sim 5.5 \mathrm{~km}$ transect roughly parallel to the seismic survey (Fig. 1c), using an acquisition system especially adapted to be towed by a motor sled traveling at approximately $10 \mathrm{~km} \mathrm{~h}^{-1}$ (e.g., Welch and 
Jacobel, 2003). The system used a Kentech pulse transmitter that produces $\pm 2000 \mathrm{~V}$ pulses with a variable pulse repetition frequency of between 1 and $5 \mathrm{kHz}$. The antennae are resistively loaded wire dipoles with a nominal frequency of $5 \mathrm{MHz}$, and the receiver uses an 8 bit NI USB-5133 digitizer and a computer. We stacked 64 traces over a $10-15 \mathrm{~m}$ horizontal distance, and then we filtered between $2-8 \mathrm{MHz}$ in postprocessing to produce each final trace on the radargram. We created a GPR reflection image by converting the radar data to depth using a radar velocity of $172 \mathrm{~m} \mathrm{ss}^{-1}$ (see Supplement).

\subsection{Basal radar reflectivity}

We estimated the relative basal reflectivity of the bed reflector along the track by first correcting for geometric spreading and then correcting for englacial attenuation assuming the englacial attenuation rate is uniform. This assumption of uniform englacial attenuation is common (e.g., Christianson et al., 2016; Palmer et al., 2013) but not ideal for this situation because horizontal variability in the thermal structure of the ice is not well constrained. We picked the peak power along our bed profile using a semi-automated picking routine, where the user provides the approximate bed picks to guide the automated routine. We assume an englacial average attenuation rate of $-15 \mathrm{~dB} \mathrm{~km}^{-1}$ which is at the lower end of the range of values suggested for northwest Greenland by MacGregor et al. (2015), which are based on tracing the return power of reflections from internal ice layers (e.g., Matsuoka et al., 2010). We chose the lower end based on fitting a linear curve to peak power versus depth for our data set, which suggests attenuation between -12 and $-20 \mathrm{~dB} \mathrm{~km}^{-1}$. This method, described by Jacobel et al. (2009) and further assessed and compared to other methods by Hills et al. (2020), has limitations for our data set because of (1) the limited depth range, (2) the limited spatial sampling, (3) scatter in the data due to noise, (4) the assumption of uniform horizontal attenuation, and (5) it only applying to the depth range of our data; therefore, we only use this estimate as a rough proxy for basal material. Because of uncertainties in the attenuation assumptions, we also provide the correction factors for $-25 \mathrm{~dB} \mathrm{~km}^{-1}$ attenuation.

\subsection{Basal seismic reflectivity}

We calculate the reflection coefficient at the base of the ice by analyzing the amplitudes of the primary bed reflection and its multiple, which we refer to as R1 and R2 from hereon. When both $\mathrm{R} 1$ and $\mathrm{R} 2$ are visible, the basal reflection coefficient $c_{\mathrm{R}}$ can be determined as a function of the incidence angle $\theta$ using Eq. (1), where $A_{\mathrm{R} 1}$ and $A_{\mathrm{R} 2}$ are the amplitude of the first and second ice bottom reflections, respectively; $a$ is the absorption coefficient; and $L$ is the raypath length of the R1 reflection (e.g., Peters et al., 2008).

$c_{\mathrm{R}}(\theta)=2 \frac{A_{\mathrm{R} 2}(\theta)}{A_{\mathrm{R} 1}(\theta)} e^{a L(\theta)}$

At a given geophone, two factors control the amplitude ratio between R1 and R2. First, R1 and R2 reflect off the lake with slightly different angles, which changes the relative amount of energy partitioned into each reflection. Second, since R2 travels farther than R1, its amplitude is diminished due to geometrical spreading and attenuation. However, at incidence angles in this study, the difference in reflection coefficients between R1 and R2 is negligible. Additionally, the path lengths of R1 and R2 vary by $<5 \%$ between their shortest and farthest offsets. Therefore, to calculate the reflection coefficient $c_{\mathrm{R}}$, we use the normal incidence approximation and compare amplitude ratios $A_{\mathrm{R} 2} / A_{\mathrm{R} 1}$ on individual seismograms. In order to minimize the influence of the air wave on $A_{\mathrm{R} 2} / A_{\mathrm{R} 1}$ ratio, we exclude data from geophones with offsets between $135-155 \mathrm{~m}$, where there is potential interference between $\mathrm{R} 1$ and the air wave. Measurements of $A_{\mathrm{R} 1}$ and $A_{\mathrm{R} 2}$ are made prior to f-k filtering.

The relationship between the absorption coefficient $a$ and the seismic quality factor $Q$ is given by Eq. (2), where $c$ is the seismic velocity and $f$ is frequency (Bentley and Kohnen, 1976). While, in principle, the spectral ratio of the R1 and R2 reflections can be used to determine the attenuation $\left(Q^{-1}\right)$ of the glacial ice (Dasgupta and Clark, 1998; Peters et al., 2012), the low signal-to-noise ratio of the R 2 reflection prevents us from making a robust measurement. Here, we estimate the absorption coefficient $a$ based on the study of Peters et al. (2012), who reported $Q=355 \pm 75$ in the upper $1 \mathrm{~km}$ of ice in Jakobshavn Isbræ, western Greenland. Using Eq. (2) with $c=3.7 \mathrm{~km} \mathrm{~s}^{-1}$ and assuming a frequency of $100 \mathrm{~Hz}$ (the predominant frequency observed in the reflections), this corresponds to an absorption factor $a=0.23 \pm 0.06 \mathrm{~km}^{-1}$.

$$
Q^{-1}=\frac{c a}{\pi f}
$$

\section{Results}

The seismic reflection profile (Fig. 2a) shows a clear ice bottom reflection (R1) across the entire transect arriving with a two-way travel time between $400-460 \mathrm{~ms}$. The ice bottom multiple R2 is also visible between $800-920 \mathrm{~ms}$. At transect distances between $0-1700 \mathrm{~m}$, the $\mathrm{R} 1$ reflection is flat and relatively uniform in character, which we interpret to be the signal of the top of the subglacial lake. In this region, R1 arrives at $457 \mathrm{~ms}$, which corresponds to a depth of $845 \mathrm{~m}$, assuming an average $V_{\mathrm{P}}$ of $3700 \mathrm{~m} \mathrm{~s}^{-1}$ within the ice. At larger transect distances, the reflections arrive earlier with increasing distance, which likely reflects the bed topography adjacent to the subglacial lake. An additional reflection is observed 


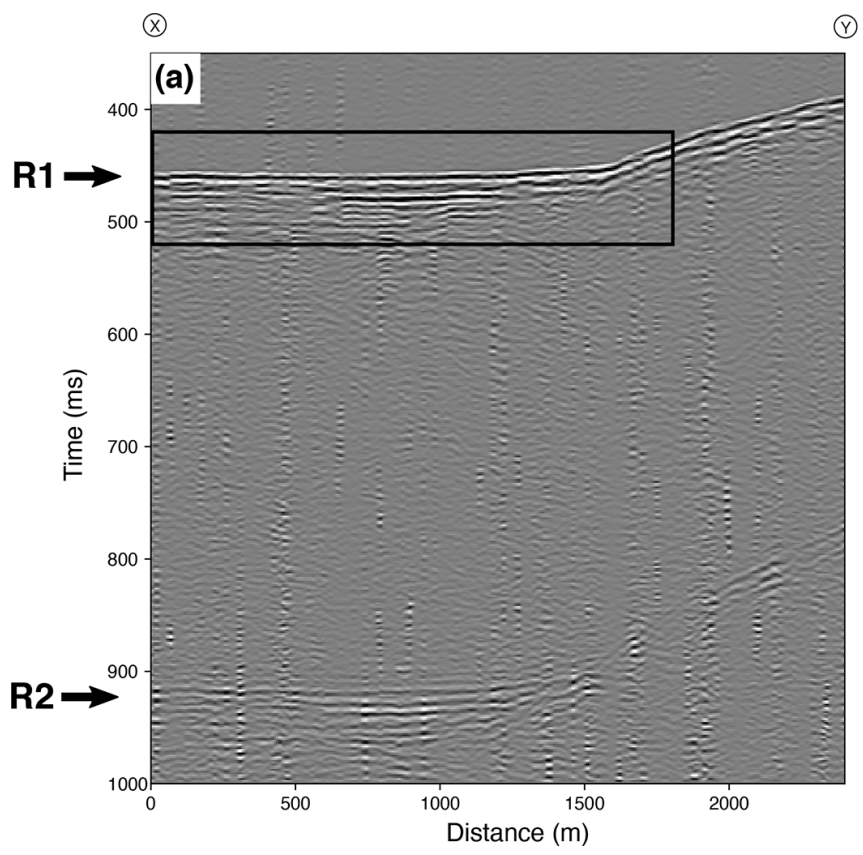

(1)
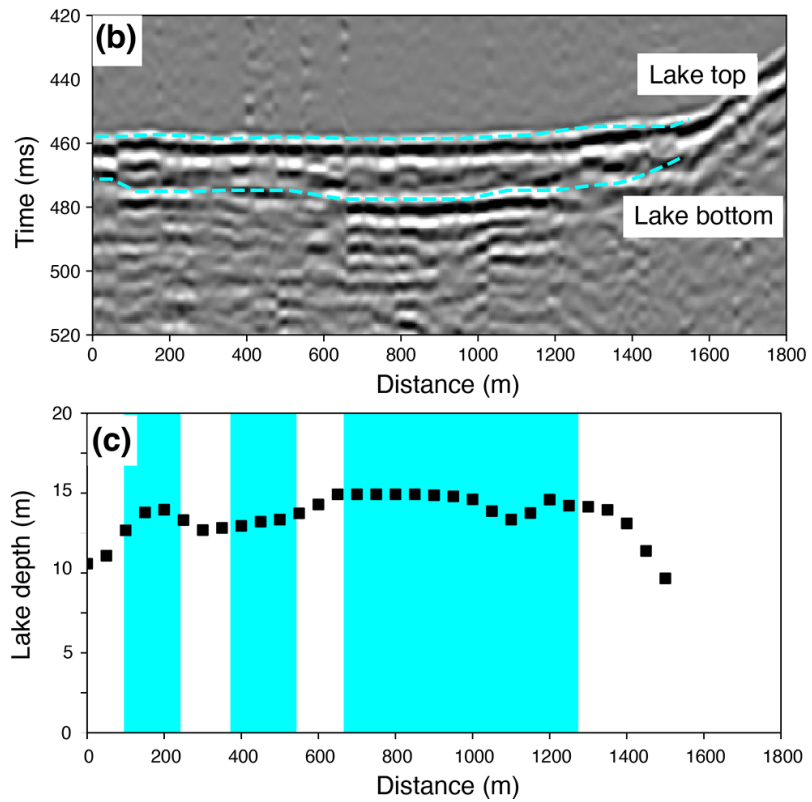

Figure 2. (a) The seismic reflection profile of the entire traverse. Reflections labeled R1 and R2 correspond to the primary reflection from the lake top and its multiple. A transect distance of $0 \mathrm{~m}$ corresponds to the southwestern end of the line. (b) A close-up of the R1 reflection window (black rectangle in panel a), showing reflections from both the lake top and the lake bottom. Travel time picks of the lake top and lake bottom reflections are drawn with the dashed blue line. The depth of the lake inferred from the picked reflections assuming a lake $V_{\mathrm{P}}$ of $1498 \mathrm{~m} \mathrm{~s}^{-1}$ is shown in (c). Blue-shaded regions indicate where the lake bottom reflection is most clearly identified.

arriving between 14-20 ms after R1, which we interpret as a lake bottom reflection (Fig. 2b). This signal is intermittently observed but is most continuous at transect distances between $660-1200 \mathrm{~m}$. The travel time differential between the lake top and lake bottom reflection is used to measure the thickness of the water column as a function of distance along the transect. Assuming $V_{\mathrm{P}}$ in the lake of $1498 \mathrm{~m} \mathrm{~s}^{-1}$ (Table 1), the lake is between $10-15 \mathrm{~m}$ deep (Fig. 2c). An uncertainty of $\pm 50 \mathrm{~m} \mathrm{~s}^{-1}$ in the seismic velocity of the lake would correspond to a lake depth uncertainty of $\pm 0.5 \mathrm{~m}$. A strong coda following the lake bottom reflection is apparent, which is likely caused by a thin $(\sim 10 \mathrm{~m})$ sediment package underlying the lake (see Discussion section).

In the GPR profile, the subglacial lake is apparent as a flat reflector at an elevation of $\sim 510 \mathrm{~m}$ along the majority of the transect (Fig. 3a). The surface topography slopes gently to the west across the transect; hence the lake top is slightly deeper (i.e., the ice is thicker) towards the east (Fig. 3b). The lake is beneath $840 \mathrm{~m}$ of ice at transect distances between 2 and $4.5 \mathrm{~km}$, which roughly corresponds to the location of the seismic survey. The transition from the lake top to the adjacent bed is observed at approximately $4100 \mathrm{~m}$ along the transect. In addition, we observe that the bed reflected power is approximately $5 \mathrm{~dB}$ higher over the lake compared to the surrounding region (Fig. 3c). Similar to the conclusion of Palmer et al. (2013), which was based on airborne radar, we infer this elevated reflectivity results from an ice-water in- terface. However, Tulaczyk and Foley (2020) show that subglacial materials with high conductivity can produce similar reflections to an ice-water interface. Additionally, Tulaczyk and Foley (2020) provide a method using information about phase and multiple frequencies to better distinguish among freshwater, brine, and water- or brine-saturated clay. Our available data, however, are at a single frequency and do not retain phase information; therefore, we do not have sufficient information to distinguish between these high-conductivity materials based on radar alone. The secondary seismic reflection discussed above suggests that the lake is water of unknown salinity, rather than saturated sediments.

Assuming an absorption factor of $a=0.23$, the average seismic reflection coefficient of the lake bottom across the transect is $-0.43 \pm 0.17$ (Fig. 4a). In Fig. $4 b$, we plot $c_{\mathrm{R}}$ calculated for each shot gather above the lake as a function of the distance along the transect. For comparison we show the expected reflection coefficients of several different geologic materials underlying glacial ice. Beyond the boundary of the lake, the R2 signal strength is diminished and we are unable to confidently measure $c_{\mathrm{R}}$. The reflection coefficients were modeled using the two-term approximation of the Zoeppritz equations (e.g., Aki and Richards, 2002; Booth et al., 2015) with the material properties shown in Table 1. In contrast to other likely geological materials at the base of the ice, liquid water is expected to have a negative reflection coefficient. The reflection coefficient modeled for lithified sediments or 

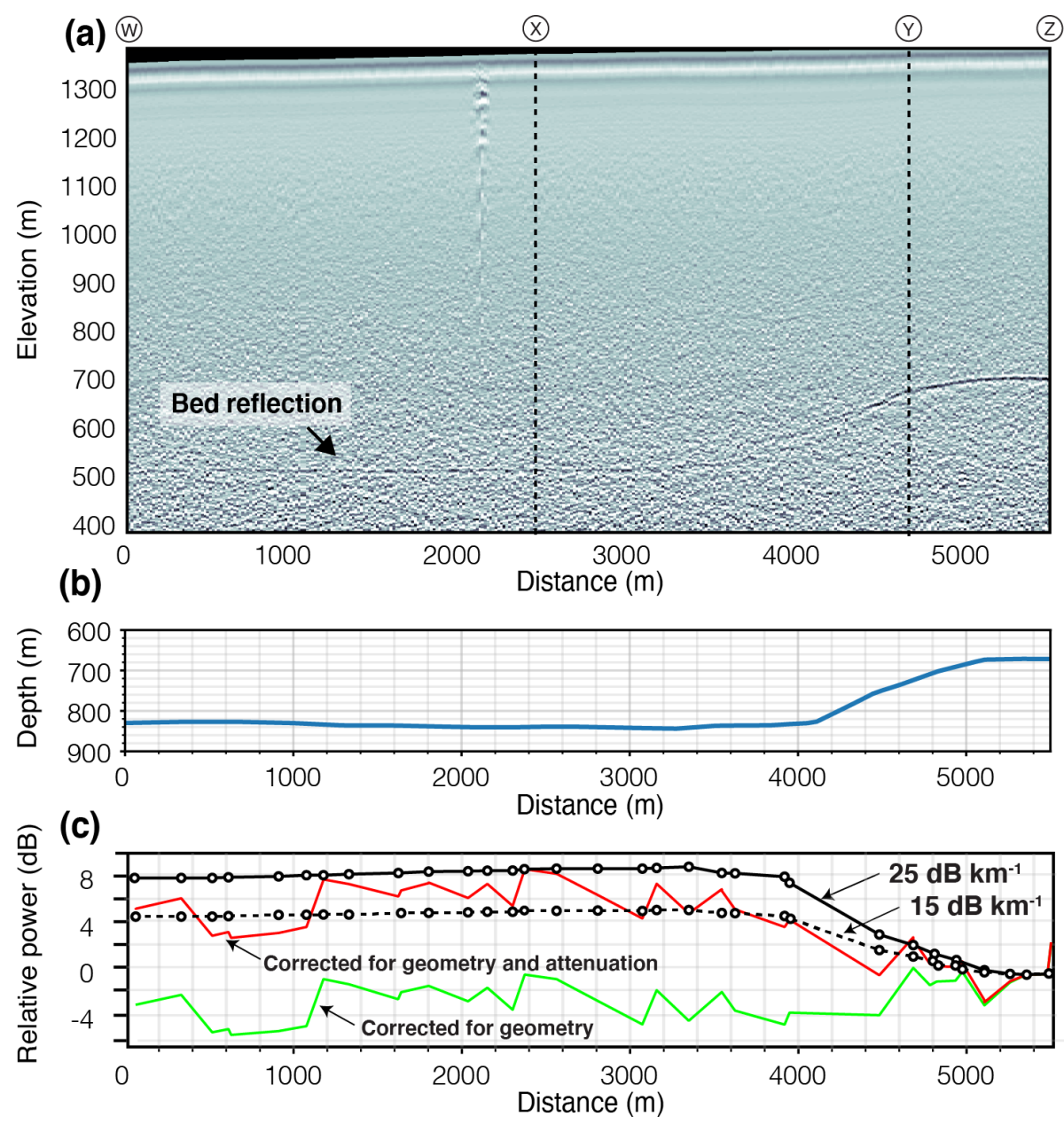

Figure 3. GPR profile. (a) The $5 \mathrm{MHz}$ radar data, unmigrated. The primary bed reflection is marked with an arrow. Vertical dashed lines mark the approximate endpoints of the seismic survey. The depth from the surface to the base of the ice is shown in (b). In panel (c), the relative power of the basal reflections is shown after being corrected for geometric spreading (green line) and both geometric spreading and depth-average attenuation of $-15 \mathrm{~dB} \mathrm{~km}^{-1}$ (red line). The solid and dashed black lines show the magnitude of attenuation corrections assuming an englacial attenuation of -25 and $-15 \mathrm{~dB} \mathrm{~km}^{-1}$, respectively.

bedrock underlying ice is similar in amplitude to liquid water but opposite in sign; thus, without polarity information sedimentary rock strata could be mistaken for a lake signature. Here, we measure R1 with an opposite polarity of the source (see Fig. S4); thus, liquid water is the most likely explanation. However, if we are significantly overestimating the magnitude of reflection coefficient due to, for example, the large uncertainties in the attenuation structure of the ice, a layer of water-saturated dilatant till may also be able to explain our data.

\section{Discussion}

\subsection{Lake geometry and volume}

If our interpretation of the observed seismic and radar reflections as signals from the lake top and bottom is correct, it implies that L2 could hold a significant volume of water. Assuming the imaged lake depth of approximately $15 \mathrm{~m}$ is representative of average lake depth throughout the roughly $10 \mathrm{~km}^{2}$ surface area determined by radio-echo sounding, we estimate the total volume of liquid water to be $0.15 \mathrm{~km}^{3}$ $(0.15 \mathrm{Gt}$ of water). While this is only a small fraction of the $217 \pm 32 \mathrm{Gt}$ of ice that Greenland is estimated to lose each year to glacier discharge and surface melting (Shepherd et al., 2019), the net storage capacity of all of Greenland's subglacial lakes could be appreciable.

To verify our interpretation of the lake top and bottom seismic reflections, we modeled synthetic seismic waveforms of the 12th shot gather in our survey, which contained some of the clearest reflections. This shot gather corresponds to transect distances between $660-720 \mathrm{~m}$ in the seismic reflection image. Synthetic seismograms were computed using SPECFEM2D (Tromp et al., 2008) for two simple layered 
(a)

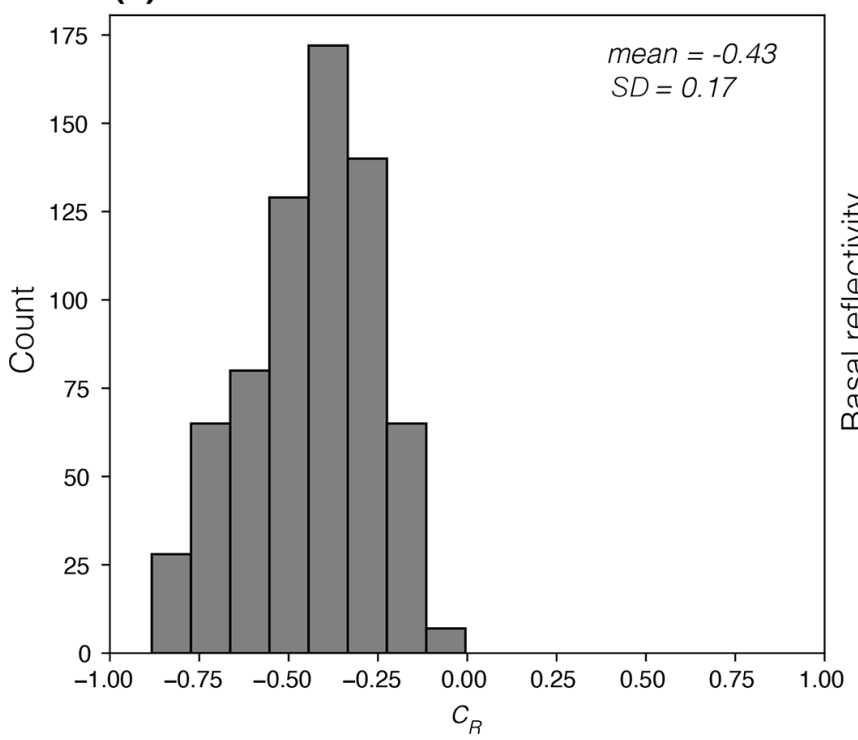

(b)

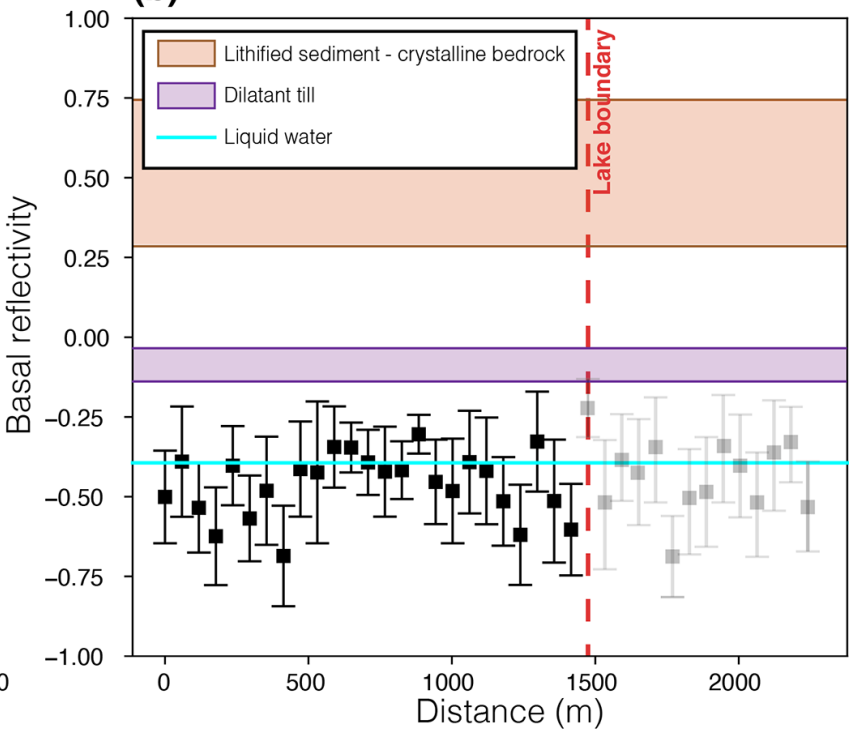

Figure 4. (a) Distribution of reflection coefficients $c_{\mathrm{R}}$ calculated for all shots in the survey. (b) Basal reflectivity as a function of distance along the transect. The black scatter points with error bars show the mean and standard deviation of $c_{\mathrm{R}}$ in a single shot gather, calculated assuming an absorption factor $a=0.23$. The shaded regions show the range of expected basal reflectivity values for bedrock or dilatant till, and the cyan line shows the basal reflectivity expected for liquid water. The approximate boundary of the subglacial lake is marked by the dashed red line. Values beyond the margin of the lake are shown with light shading because they cannot be confidently interpreted due to the low signal strength of the $\mathrm{R} 2$ reflection.

Table 1. Description of material properties used in reflection coefficient modeling.

\begin{tabular}{lrrr}
\hline Material & $V_{\mathrm{P}}\left(\mathrm{m} \mathrm{s}^{-1}\right)$ & $V_{\mathrm{S}}\left(\mathrm{m} \mathrm{s}^{-1}\right)$ & Density $\left(\mathrm{kg} \mathrm{m}^{-3}\right)$ \\
\hline Glacial ice & $3810^{\mathrm{a}}$ & $1860^{\mathrm{a}}$ & $920^{\mathrm{a}}$ \\
Water & $1498^{\mathrm{a}}$ & 0 & 1000 \\
Dilatant sediment & $1600-1800^{\mathrm{b}}$ & $100-500^{\mathrm{b}}$ & $1600-1800^{\mathrm{b}}$ \\
Lithified sediment & $3000^{\mathrm{b}}-3750^{\mathrm{a}}$ & $1200^{\mathrm{b}}-2450^{\mathrm{a}}$ & $2200^{\mathrm{b}}-2450^{\mathrm{a}}$ \\
Bedrock & $5200^{\mathrm{a}}-6200^{\mathrm{b}}$ & $2700^{\mathrm{a}}-3400^{\mathrm{b}}$ & $2700^{\mathrm{a}}-2800^{\mathrm{b}}$ \\
\hline
\end{tabular}

${ }^{a}$ Values are compiled from Peters et al. (2008). ${ }^{b}$ Values are compiled from Christianson et al. (2014).

models of a $12 \mathrm{~m}$ thick lake underlying $850 \mathrm{~m}$ of glacial ice. In the first model the lake is underlain by a thick layer of sediments that extends to the bottom of the model domain. In the second model there is $10 \mathrm{~m}$ of sediments overlying a discontinuity with the bedrock below. The seismic velocity profiles for the two cases are shown in the insets in Fig. 5b and c. The source used in the simulations was a Ricker wavelet with a dominant frequency of $100 \mathrm{~Hz}$. Figure 5 shows a comparison between the observations and synthetics. In both the observed (Fig. 5a) and synthetic (Fig. 5b and c) shot gathers, the lake top and lake bottom reflections are separated by $\sim 20 \mathrm{~ms}$ and show a clear polarity reversal, which reflects the opposite sign of the acoustic impedance contrast between an ice-water and a water-lake bed transition. The observed shot gather contains a coda following the lake bottom reflection that is absent in the synthetics that do not include a disconti- nuity at the base of the sediment package (Fig. 5b). When a discontinuity between the sediment and underlying bedrock is included, a strong sediment bottom reflection is introduced which more closely matches the observations (Fig. 5c). In the observed data it is difficult to clearly identify a sediment bottom reflection since the complex coda could be caused by reverberations within a thin sediment sequence or many superposed reflections from individual discontinuities. However, if the first positive peak following the lake bottom reflection represents the base of the sediment, we can estimate a sediment thickness of $8.5 \mathrm{~m}$ assuming a sediment $V_{\mathrm{P}}$ of $1700 \mathrm{~m} \mathrm{~s}^{-1}$ (Table 1).

\subsection{Lake origin}

While our results suggest that L2 is indeed a subglacial lake, its presence is perplexing given its location with a mean an- 

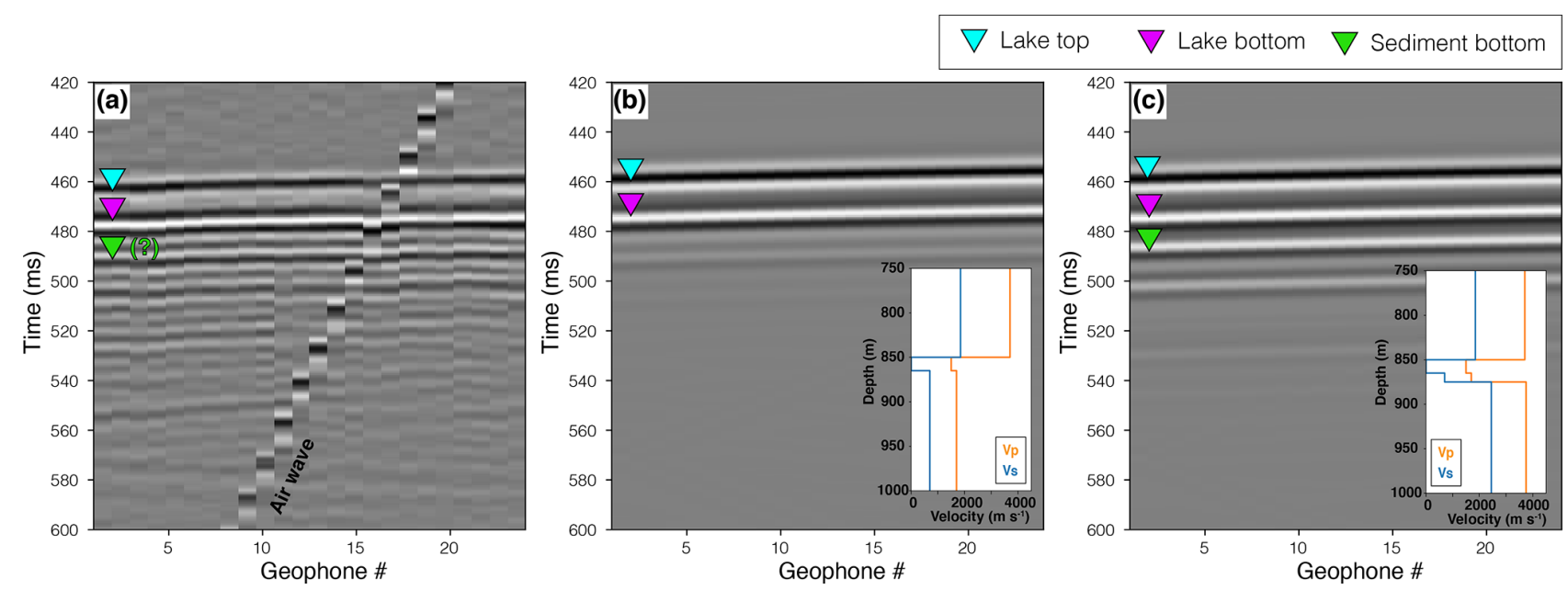

Figure 5. Observed (a) and synthetic (b, c) seismic data for shot gather 12 bandpass filtered between 50-200 Hz. The offset from the source to geophone 1 is $230 \mathrm{~m}$. The colored triangles indicate reflections from the lake top (blue), lake bottom (purple), and sediment bottom (green). The insets in panels (b) and (c) show the $V_{\mathrm{P}}$ and $V_{\mathrm{S}}$ models that were used to compute the synthetics. Both models include a $12 \mathrm{~m}$ thick lake below $850 \mathrm{~m}$ of ice. The model used in (c) includes an additional discontinuity $10 \mathrm{~m}$ below the lake, which represents the boundary between the lake bottom sediments and underlying bedrock.

nual surface temperature of $-22^{\circ} \mathrm{C}$ and its position beneath a relatively thin column of glacial ice. In contrast to many well-studied subglacial lakes below the Antarctic ice sheet, such as Lake Vostok, that lie below $\sim 4 \mathrm{~km}$ of ice, the basal temperature at our field site is expected to be well below the pressure-dependent melting point of ice. Distinguishing between the different hypotheses of subglacial lake formation has implications for the stability and dynamics of the Greenland ice sheet since they predict different basal thermal and hydrological conditions. Thus, constraining the temperature of L2 is an important goal.

We determine the range of possible basal temperatures using a 1D steady-state advection-diffusion heat transfer model solved using the control volume method (see Supplement). The modeling assumes an ice density of $\rho=920 \mathrm{~kg} \mathrm{~m}^{-3}$, a heat capacity of $c_{P}=2000 \mathrm{~J} \mathrm{~kg}^{-1} \mathrm{~K}^{-1}$, and a thermal conductivity of ice of $k=2.3 \mathrm{~W} \mathrm{~m}^{-1} \mathrm{~K}^{-1}$. The basal geothermal heat flux $q$ is varied between $50-60 \mathrm{~mW} \mathrm{~m}^{-2}$, which is consistent with estimates derived from magnetic data (Martos et al., 2018) and thermal isostasy modeling (Artemieva, 2019). Figure 6 shows results for surface temperatures $T_{\mathrm{S}}$ of -20 and $-22^{\circ} \mathrm{C}$ and ice-equivalent accumulation rates $w$ ranging from 0 to $0.3 \mathrm{~m} \mathrm{yr}^{-1}$. When vertical advection is ignored (i.e., no ice accumulation), most scenarios predict frozen bed conditions with the exception of the relatively warm surface condition $\left(T_{\mathrm{S}}=-20^{\circ} \mathrm{C}\right)$ and high heat flow $\left(q=60 \mathrm{~mW} \mathrm{~m}^{-2}\right)$ scenario (Fig. 6a). When ice accumulation is considered, all scenarios predict frozen bed conditions (Fig. 6b). For an ice-equivalent accumulation rate of $0.3 \mathrm{~m} \mathrm{yr}^{-1}$, which most closely matches the conditions of the field site, and regional average geothermal flux, the basal temperature is expected to be between approximately -12 and $-14{ }^{\circ} \mathrm{C}$.
There are several possible explanations for the existence of liquid water underneath the ice, including hypersalinity, recharge by surface meltwater, high geothermal flux, and latent heat from freezing. Here, we review these explanations and assess their specific relevance to lake L2.

1. Hypersalinity. If the lake is hypersaline, the lake water could remain liquid at low temperatures by depressing the freezing temperature. In order to depress the freezing temperature of water by 12 to $14^{\circ} \mathrm{C} \mathrm{a} \mathrm{NaCl}$ concentration of roughly 160 to $180 \mathrm{ppt}$ would be required, $6 \times$ that of seawater (e.g., Fofonoff and Millard, 1983). If the hypersaline condition is restricted to the lake, the surrounding ice would likely be frozen to the bed and would form a closed hydrological system that could remain isolated on geologic timescales. In this scenario, the lake could represent a body of ancient marine water that was trapped as glacial ice advanced over the area and was potentially further enriched in salt through cryogenic concentration processes (Lyons et al., 2005, 2019). Similar hypersaline lakes with salt concentrations several times higher than seawater are known to exist below the McMurdo Dry Valleys in Antarctica (Hubbard et al., 2004; Lyons et al., 2005, 2019; Mikucki et al., 2009) and in the Devon Ice Cap, Canada (Rutishauser et al., 2018). Because the current elevation of the lake is more than $500 \mathrm{~m}$ above sea level, it is unlikely to be trapped seawater as in the McMurdo Dry Valleys. While an ancient evaporite deposit is possible, as is proposed for the Devon Ice Cap (Rutishauser et al., 2018), the geologic map of Greenland does not indicate likely evaporites in this area (Dawes, 2004). 
(a)
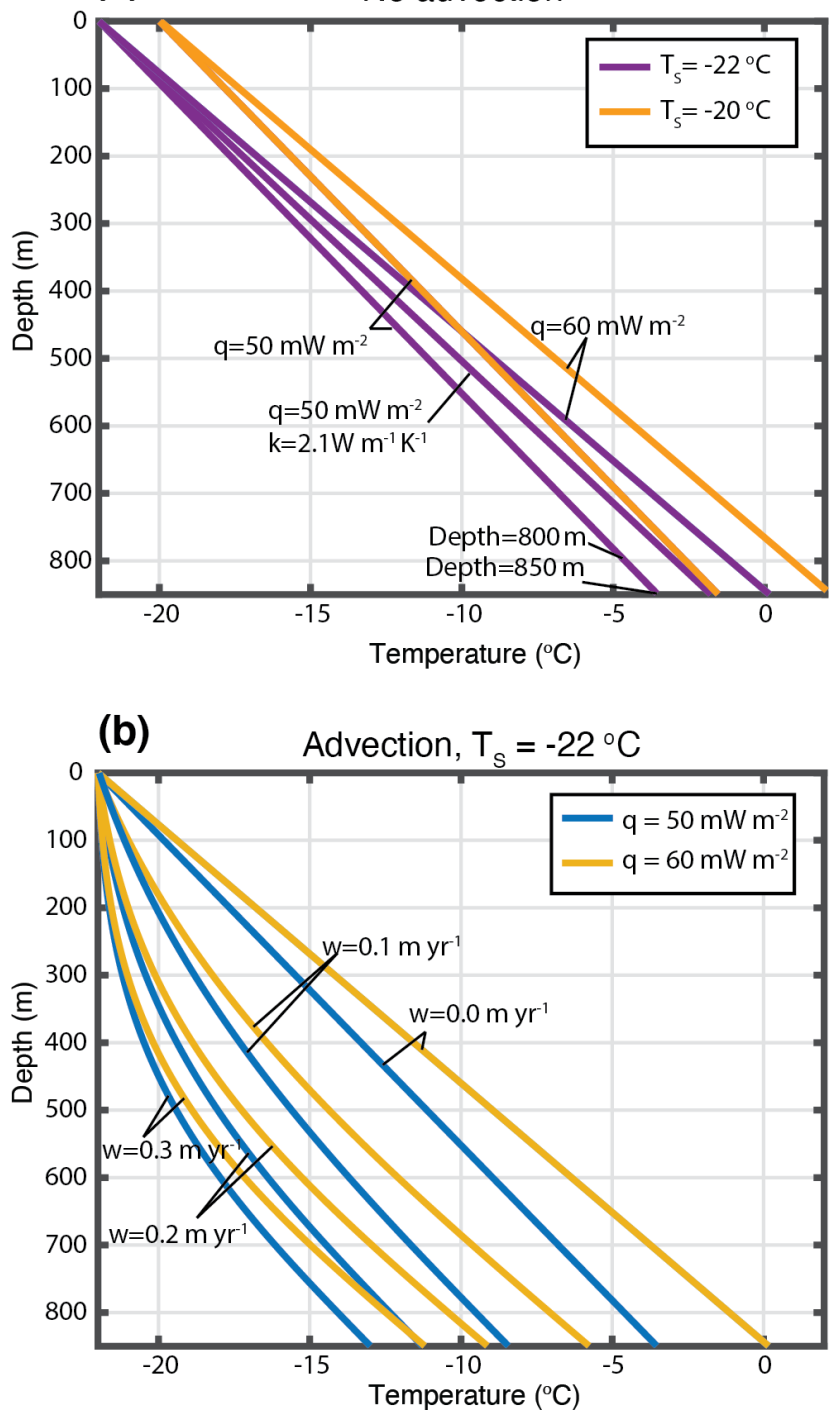

Figure 6. Modeled ice-sheet thermal structure. Panel (a) shows thermal profiles neglecting advection for surface temperatures of $T_{\mathrm{S}}=-22^{\circ} \mathrm{C}$ and $T_{\mathrm{S}}=-20^{\circ} \mathrm{C}$. Panel (b) shows thermal profiles including advection for a fixed surface temperature of $T_{\mathrm{S}}=$ $-22{ }^{\circ} \mathrm{C}$. The basal heat flux $q$ is varied between $50-60 \mathrm{~mW} \mathrm{~m}^{-2}$, and the accumulation rate $w$ is varied between 0 and $0.3 \mathrm{~m} \mathrm{yr}^{-1}$.

2. Surface meltwater. The lake may be part of an open hydrological system that is continually recharged by surface meltwater. If the hydrological system is connected and the rate of recharge matches or exceeds the rate of freezing, a lake could persist despite sub-freezing temperatures in the lower part of the ice. At other locations in Greenland, observations of vertical surface deformation and collapse features have suggested that surface meltwater plays a prominent role in subglacial lake formation and dynamics (Palmer et al., 2015; Willis et al., 2015). This lake, however, is in the high-elevation ac- cumulation area of the ice sheet, near the ice divide (Fig. 1b), and there are no obvious sources of significant surface recharge visible on the ground or from satellite imagery. To determine possible pathways for surface recharge from more distant features, we estimate the local hydraulic head based on surface and bed elevations (Fig. S5) and find no pathways given the present resolution of the bed and surface topography. It is possible that a subglacial pathway exists that is smaller than the resolution of BedMachine (Morlighem et al., 2017).

3. High geothermal flux. Anomalously high basal heat flux may promote melting of the ice sheet from below (e.g., Fahnestock et al., 2001; Rogozhina et al., 2016). If this is the case, the local geothermal heat flux must greatly exceed regional estimates of the geothermal heat flux beneath the northwestern Greenland ice sheet, which are typically in the range of $50-60 \mathrm{~mW} \mathrm{~m}^{-2}$ (Artemieva, 2019; Martos et al., 2018; Rogozhina et al., 2016). Based on the one-dimensional model shown in Fig. 6, a geothermal flux on the order of $100 \mathrm{~mW} \mathrm{~m}^{-2}$ would be necessary to sustain the lake. While high heat flux in this region is unexpected based on the cratonic bedrock geology and lack of recent volcanism, a local region of high heat flux could be promoted by the presence of upper crustal granitoids rich in radiogenic heat-producing elements or hydrothermal fluid migration through preexisting fault systems (e.g., Jordan et al., 2018).

4. Latent heat from freezing. For the isolated lake of actively freezing brine (as in Hypothesis 1), the hydrologically connected continuous flow (Hypothesis 2), or if the lake is a relic of a larger freshwater body that is slowly freezing, the thermal profile of the ice would show a curvature change at depth due to a latent heat source at the bottom boundary. Given a latent heat of freezing of $334 \mathrm{~J} \mathrm{~g}^{-1}$, freezing a layer $1 \mathrm{~m}$ thick to the bottom of the ice over 1 year is roughly equivalent to increasing the geothermal flux by $10 \mathrm{~mW} \mathrm{~m}^{-2}$.

Sustaining a freezing rate of several $\mathrm{m} \mathrm{yr}^{-1}$ to generate the latent heat necessary to maintain warm basal ice is less likely than a locally elevated geothermal anomaly. We, therefore, narrow the lake origin hypotheses to either anomalously high geothermal flux or hypersalinity due to local ancient evaporite. Measuring the thermal profile and vertical velocity and strain rates above this lake would provide important information to assess these hypotheses. For a freshwater lake created by high geothermal flux, the basal ice temperature would be near $0^{\circ} \mathrm{C}$, and vertical velocity would be downward if melting exceeds accumulation. For a lake created by evaporite, the basal ice would be substantially below zero, and the vertical velocity would be near zero or upward (due to freezing). A geothermally created lake would show higher vertical strain rates in the lower part of the ice column than an evaporite-created lake. 
A freshwater lake and a hypersaline lake have different physical properties and thus may have different signatures that could be detected in geophysical surveys. Radar reflections from an ice-brine boundary undergoing freezing and cryoconcentration of the brine are known to cause scattering and decrease the reflectivity (Badgeley et al., 2017), which we do not see in our data; this provides a second justification to rule out modern active cryoconcentration; in addition, sustained freezing of any ice is likely to create a radar-detectable basal ice unit such as that suggested by Bell et al. (2014).

Further, because the seismic velocity and density of water depends on temperature and salinity, we would expect that lakes formed by different mechanisms would have slightly different basal reflection coefficients, although the small variations expected in $c_{\mathrm{R}}$ would not be resolvable with our data set. On the other hand, because the electrical resistivity of water is strongly dependent on salinity, magnetic sounding could provide useful constraints on lake composition. Additionally, since radar attenuation is strongly sensitive to lake conductivity, radio-echo sounding amplitude data could potentially help constrain salinity if lake bed returns are observed in shallow areas. Stronger constraints could potentially be placed on subglacial properties if a stronger activesource were used (e.g., explosives), since data with a high signal-to-noise ratio could be recorded at larger distances. This would be particularly useful for measuring the basal reflectivity as a function of the incidence angle, which would help verify our interpretation of a subglacial lake. Repeated seismic reflection or GPR surveys calculated along the same transect could provide clues to whether or not lake levels are changing over time (e.g., Church et al., 2020). Finally, direct sampling with drilling would provide the best measurements on subglacial lake properties and could also yield useful biological and paleoenvironmental information.

\section{Conclusions}

We conducted an active-source seismic reflection and GPR survey in northwestern Greenland above a site that was previously identified as a possible subglacial lake. We observed a horizontal reflector across the majority survey with a seismic reflection coefficient of $-0.43 \pm 0.17$, consistent with the presence of a lake below approximately $830-845 \mathrm{~m}$ of ice. Additionally, we observed a lake bottom reflection near the center of our seismic profile consistent with a lake depth of approximately $15 \mathrm{~m}$. From previous observations of the lateral extent of the lake based on airborne radio-echo sounding (Palmer et al., 2013), we estimate the subglacial lake holds a total of $0.15 \mathrm{Gt}$ of water. A strong coda arriving after the lake-bottom reflection suggests that the lake is underlain by a sedimentary package, but its thickness and material properties are uncertain. To the authors knowledge, this is the first time a ground-based geophysical survey has confirmed the existence of a subglacial lake in Greenland and provided constraints on its depth. Understanding the nature and origins of recently detected subglacial lakes in Greenland is important since wet basal conditions enable glacial ice to flow more easily which can further promote ice loss. Our analysis of the seismic and radar, as well as thermal and hydropotential, analysis narrow the lake origins to either locally high geothermal flux or an ancient evaporite deposit. Future work, such as additional geophysical investigations or drilling expeditions, should focus on constraining the temperature and salinity of the lake which will provide clues to its origin.

Code availability. All seismic processing performed in this study was performed using ObsPy (Beyreuther et al., 2010), which is an openly available Python-based software package.

Data availability. Active-source seismic data, including a full description of the data set, are available through the Digital Repository at the University of Maryland (https://doi.org/10.13016/yy2o-nhua, Schmerr et al., 2021). GPR data are available on request from the corresponding author.

Supplement. The supplement related to this article is available online at: https://doi.org/10.5194/tc-15-3279-2021-supplement.

Author contributions. This project was conceptualized by the SIIOS (Seismometer to Investigate Ice and Ocean Structure) team. Analysis of the seismic data was performed by RM and CG with support from NS and KR. EP performed the GPR analysis and thermal modeling. RM was the lead on manuscript writing and figure preparation, with significant inputs from EP, NS, and KR. Authors DND, NW, BA, AGM, NH were essential for data collection and curation. JIB, VJB, and SHB were project administrators and also provided critical review and commentary.

Competing interests. The authors declare that they have no conflict of interest.

Disclaimer. Publisher's note: Copernicus Publications remains neutral with regard to jurisdictional claims in published maps and institutional affiliations.

Acknowledgements. The authors thank SIIOS (Seismometer to Investigate Ice and Ocean Structure) team members Chris Carr and Renee Weber for helpful discussions. Additionally, we thank the editor Evgeny A. Podolskiy, the two anonymous reviewers, and Jacob Buffo for feedback that helped improve this study. Logistical support for fieldwork in northwestern Greenland was provided by Susan Detweiler. 
Financial support. Funding for this work was provided by the NASA Planetary Science and Technology Through Analog Research (PSTAR) (grant no. 80NSSC17K0229). Additionally, Nicholas Schmerr received support from the NASA Solar System Exploration Research Virtual Institute (SSERVI) Geophysical Exploration of the Dynamics and Evolution of the Solar System (GEODES) (grant no. 80NSSC19M0216).

Review statement. This paper was edited by Evgeny A. Podolskiy and reviewed by two anonymous referees.

\section{References}

Achberger, A. M., Christner, B. C., Michaud, A. B., Priscu, J. C., Skidmore, M. L., Vick-Majors, T. J., Adkins, W., Anandakrishnan, S., Barbante, C., Barcheck, G., and Beem, L.: Microbial community structure of subglacial lake Whillans, West Antarctica, Front. Microbiol., 7, 1457, https://doi.org/10.3389/fmicb.2016.01457, 2016.

Aki, K. and Richards, P. G.: Quantitative Seismology, University Science Books, Sausalito, CA, 2nd edn., 123-144, 2002.

Artemieva, I. M.: Lithosphere thermal thickness and geothermal heat flux in Greenland from a new thermal isostasy method, Earth-Sci. Rev., 188, 469-481, https://doi.org/10.1016/j.earscirev.2018.10.015, 2019.

Badgeley, J. A., Pettit, E. C., Carr, C. G., Tulaczyk, S., Mikucki, J. A., and Lyons, W. B.: An englacial hydrologic system of brine within a cold glacier: Blood Falls, McMurdo Dry Valleys, Antarctica, J. Glaciol., 63, 387-400, https://doi.org/10.1017/jog.2017.16, 2017.

Bell, R. E., Studinger, M., Shuman, C. A., Fahnestock, M. A., and Joughin, I.: Large subglacial lakes in East Antarctica at the onset of fast-flowing ice streams, Nature, 445, 904-907, https://doi.org/10.1038/nature05554, 2007.

Bell, R. E., Tinto, K., Das, I., Wolovick, M., Chu, W., Creyts, T. T., Frearson, N., Abdi, A., and Paden, J. D.: Deformation, warming and softening of Greenland's ice by refreezing meltwater, Nat. Geosci., 7, 497-502, https://doi.org/10.1038/ngeo2179, 2014.

Bentley, C. R. and Kohnen, H.: Seismic refraction measurements of internal friction in Antarctic ice, J. Geophys. Res., 81, 15191526, https://doi.org/10.1029/JB081i008p01519, 1976.

Bentley, M. J., Christoffersen, P., Hodgson, D. A., Smith, A. M., Tulaczyk, S., and Le Brocq, A. M.: Subglacial lake sediments and sedimentary processes: potential archives of ice sheet evolution, past environmental change, and the presence of life, in: Antarctic Subglacial Aquatic Environments, American Geophysical Union, Washington, D.C., 83-110, 2011.

Beyreuther, M., Barsch, R., Krischer, L., Megies, T., Behr, Y., and Wassermann, J.: ObsPy: A Python toolbox for seismology, Seismol. Res. Lett., 81, 530-533, https://doi.org/10.1785/gssrl.81.3.530, 2010.

Booth, A. D., Emir, E., and Diez, A.: Approximations to seismic AVA responses: Validity and potential in glaciological applications, Geophysics, 81, 1-11, https://doi.org/10.1190/geo20150187.1, 2016.

Bowling, J. S., Livingstone, S. J., Sole, A. J., and Chu, W.: Distribution and dynamics of Greenland subglacial lakes, Nat.
Commun., 10, 1-11, https://doi.org/10.1038/s41467-019-10821w, 2019.

Campen, R., Kowalski, J., Lyons, W. B., Tulaczyk, S., Dachwald, B., Pettit, E., Welch, K. A., and Mikucki, J. A.: Microbial diversity of an Antarctic subglacial community and highresolution replicate sampling inform hydrological connectivity in a polar desert, Environ. Microbiol., 21, 2290-2306, https://doi.org/10.1111/1462-2920.14607, 2019.

Christianson, K., Peters, L. E., Alley, R. B., Anandakrishnan, S., Jacobel, R. W., Riverman, K. L., Muto, A., and Keisling, B. A.: Dilatant till facilitates ice-stream flow in northeast Greenland, Earth Planet. Sc. Lett., 401, 57-69, https://doi.org/10.1016/j.epsl.2014.05.060, 2014.

Christianson, K., Jacobel, R. W., Horgan, H. J., Alley, R. B., Anandakrishnan, S., Holland, D. M., and DallaSanta, K. J.: Basal conditions at the grounding zone of Whillans Ice Stream, West Antarctica, from ice-penetrating radar, J. Geophys. Res.Earth, 121, 1954-1983, https://doi.org/10.1002/2015JF003806, 2016.

Church, G., Grab, M., Schmelzbach, C., Bauder, A., and Maurer, H.: Monitoring the seasonal changes of an englacial conduit network using repeated ground-penetrating radar measurements, The Cryosphere, 14, 3269-3286, https://doi.org/10.5194/tc-143269-2020, 2020.

Dasgupta, R. and Clark, R.A.: Estimation of Q from surface seismic reflection data, Geophysics, 63, 2120-2128, https://doi.org/10.1190/1.1444505, 1998.

Dawes, P. R.: Explanatory notes to the geological map of Greenland, 1:500000, Humboldt Gletscher, Sheet 6, Geological Survey of Denmark and Greenland Map Series, 1, 1-48, https://doi.org/10.34194/geusm.v1.4615, 2004.

Dee, D. P., Uppala, S. M., Simmons, A. J., Berrisford, P., Poli, P., Kobayashi, S., Andrae, U., Balmaseda, M. A., Balsamo, G., Bauer, P., Bechtold, P., Beljaars, A. C. M., van de Berg, L., Bidlot, J., Bormann, N., Delsol, C., Dragani, R., Fuentes, M., Geer, A. J., Haimberger, L., Healy, S. B., Hersbach, H., Hólm, E. V., Isaksen, L., Kållberg, P., Köhler, M., Matricardi, M., McNally, A. P., Monge-Sanz, B. M., Morcrette, J. J., Park, B. K., Peubey, C., de Rosnay, P., Tavolato, C., Thépaut, J. N., and Vitart, F.: The ERA-Interim reanalysis: configuration and performance of the data assimilation system, Q. J. Roy. Meteor. Soc., 137, 553-597, https://doi.org/10.1002/qj.828, 2011.

Fahnestock, M., Abdalati, W., Joughin, I., Brozena, J., and Gogineni, P.: High geothermal heat flow, basal melt, and the origin of rapid ice flow in central Greenland, Science, 294, 2338-2342, https://doi.org/10.1126/science.1065370, 2001.

Filina, I. Y., Blankenship, D. D., Thoma, M., Lukin, V. V., Masolov, V. N., and Sen, M. K.: New 3D bathymetry and sediment distribution in Lake Vostok: Implication for preglacial origin and numerical modeling of the internal processes within the lake, Earth Planet. Sc. Lett., 276, 106-114, https://doi.org/10.1016/j.epsl.2008.09.012, 2008.

Fofonoff, N. P. and Millard Jr., R. C.: Algorithms for computation of fundamental properties of seawater, Unesco Tech. Pap. Mar. Sci., 44, 1-58, 1983.

Fricker, H. A., Scambos, T., Bindschadler, R., and Padman, L.: An Active Subglacial Water System in West Antarctica Mapped from Space, Science, 315, 1544-1548, https://doi.org/10.1126/science.1136897, 2007. 
Hills, B. H., Christianson, K., and Holschuh, N.: A framework for attenuation method selection evaluated with ice-penetrating radar data at south pole lake, Ann. Glaciol., 61, 176-187, https://doi.org/10.1017/aog.2020.32, 2020.

Horgan, H. J., Anandakrishnan, S., Jacobel, R. W., Christianson, K., Alley, R. B., Heeszel, D. S., Picotti, S., and Walter, J. I.: Subglacial Lake Whillans-Seismic observations of a shallow active reservoir beneath a West Antarctic ice stream, Earth Planet. Sc. Lett., 331, 201-209, https://doi.org/10.1016/j.epsl.2012.02.023, 2012.

Hubbard, A., Lawson, W., Anderson, B., Hubbard, B., and Blatter, H.: Evidence for subglacial ponding across Taylor Glacier, Dry Valleys, Antarctica, Ann. Glaciol., 39, 79-84, https://doi.org/10.3189/172756404781813970, 2004.

Jacobel, R. W., Welch, B. C., Osterhouse, D., Pettersson, R., and Gregor, J. A. M.: Spatial variation of radar-derived basal conditions on Kamb Ice Stream, West Antarctica, Ann. Glaciol., 50, 10-16, https://doi.org/10.3189/172756409789097504, 2009.

Jordan, T., Martin, C., Ferraccioli, F., Matsuoka, K., Corr, H., Forsberg, R., Olesen, A., and Siegert, M.: Anomalously high geothermal flux near the South Pole, Sci. Rep.-UK, 8, 16785, https://doi.org/10.1038/s41598-018-35182-0, 2018.

Jordan, T. M., Cooper, M. A., Schroeder, D. M., Williams, C. N., Paden, J. D., Siegert, M. J., and Bamber, J. L.: Self-affine subglacial roughness: consequences for radar scattering and basal water discrimination in northern Greenland, The Cryosphere, 11, 1247-1264, https://doi.org/10.5194/tc-11-1247-2017, 2017.

Langley, K., Kohler, J., Matsuoka, K., Sinisalo, T., Scambos, T., Neumann, T., Muto, A., Winther, J.-G., and Albert, M.: Recovery Lakes, East Antarctica: Radar assessment of sub-glacial water extent, Geophys. Res. Lett., 38, L05501, https://doi.org/10.1029/2010GL046094, 2011.

Lyons, W. B., Welch, K. A., Snyder, G., Olesik, J., Graham, E. Y., Marion, G. M., and Poreda, R. J.: Halogen geochemistry of the McMurdo Dry Valleys lakes, Antarctica: clues to the origin of solutes and lake evolution, Geochim. Cosmochim. Ac., 69, 305323, https://doi.org/10.1016/j.gca.2004.06.040, 2005.

Lyons, W. B., Mikucki, J. A., German, L. A., Welch, K. A., Welch, S. A., Gardner, C. B., Tulaczyk, S. M., Pettit, E. C., Kowalski, J., and Dachwald, B.: The geochemistry of englacial brine from Taylor Glacier, Antarctica, J. Geophys. Res.-Biogeo., 124, 633648, https://doi.org/10.1029/2018JG004411, 2019.

MacGregor, J., Li, J., Paden, J., Catania, G., Clow, G., Fahnestock, M., Gogineni, S., Grimm, R., Morlighem, M., Nandi, S., Seroussi, H., and Stillman, D.: Radar attenuation and temperature within the Greenland Ice Sheet, J. Geophys. Res.-Sol. Ea., 120, 983-1008, https://doi.org/10.1002/2014JF003418, 2015.

MacGregor, J. A., Fahnestock, M. A., Catania, G. A., Aschwanden, A., Clow, G. D., Colgan, W. T., Gogineni, S. P., Morlighem, M., Nowicki, S. M. J., Paden, J. D., Price, S. F., and Seroussi, H.: A synthesis of the basal thermal state of the Greenland Ice Sheet, J. Geophys. Res.-Earth, 121, 1328-1350, https://doi.org/10.1002/2015JF003803, 2016.

Martos, Y. M., Jordan, T. A., Catalan, M., Jordan, T. M., Bamber, J. L., and Vaughan, D. G.: Geothermal heat flux reveals the Iceland hotspot track underneath Greenland, Geophys. Res. Lett., 45, 8214-8222, https://doi.org/10.1029/2018GL078289, 2018.

Matsuoka, K., Morse, D., and Raymond, C. F.: Estimating englacial radar attenuation using depth profiles of the returned power, central West Antarctica, J. Geophys. Res., 115, 1-15, https://doi.org/10.1029/2009JF001496, 2010.

Mikucki, J. A., Pearson, A., Johnston, D. T., Turchyn, A. V., Farquhar, J., Schrag, D. P., Anbar, A. D., Priscu, J. C., and Lee, P. A.: A contemporary microbially maintained subglacial ferrous "Ocean", Science, 324, 397-400, https://doi.org/10.1126/science.1167350, 2009.

Morlighem, M., Williams, C. N., Rignot, E., An, L., Arndt, J. E., Bamber, J. L., Catania, G., Chauche, N., Dowdeswell, J. A., Dorschel, B., Fenty, I., Hogan, K., Howat, I., Hubbard, A., Jakobsson, M., Jordan, T. M., Kjeldsen, K. K., Millan, R., Mayer, L., Mouginot, J., Noel, B. P. Y., O'Cofaigh, C., Palmer, S., Rysgaard, S., Seroussi, H., Siegert, M. J., Slabon, P., Straneo, F., van den Broeke, M. R., Weinrebe, W., Wood, M., and Zinglersen, K. B.: BedMachine v3: Complete Bed Topography and Ocean Bathymetry Mapping of Greenland From Multibeam Echo Sounding Combined With Mass Conservation, Geophys. Res. Lett., 44, 11051-11061, https://doi.org/10.1002/2017GL074954, 2017.

Noël, B., van de Berg, W. J., van Wessem, J. M., van Meijgaard, E., van As, D., Lenaerts, J. T. M., Lhermitte, S., Kuipers Munneke, P., Smeets, C. J. P. P., van Ulft, L. H., van de Wal, R. S. W., and van den Broeke, M. R.: Modelling the climate and surface mass balance of polar ice sheets using RACMO2 Part 1: Greenland (1958-2016), The Cryosphere, 12, 811-831, https://doi.org/10.5194/tc-12-811-2018, 2018.

Palmer, S. J., Dowdeswell, J. A., Christoffersen, P., Young, D. A., Blankenship, D. D., Greenbaum, J. S., Benham, T., Bamber, J., and Siegert, M. J.: Greenland subglacial lakes detected by radar, Geophys. Res. Lett., 40, 6154-6159, https://doi.org/10.1002/2013GL058383, 2013.

Palmer, S., McMillan, M., and Morlighem, M.: Subglacial lake drainage detected beneath the Greenland ice sheet, Nat. Commun., 6, 8408, https://doi.org/10.1038/ncomms9408, 2015.

Peters, L. E., Anandakrishnan, S., Holland, C. W., Horgan, H. J., Blankenship, D. D., and Voigt, D. E.: Seismic detection of a subglacial lake near the South Pole, Antarctica, Geophys. Res. Lett., 35, L23501, https://doi.org/10.1029/2008GL035704, 2008.

Peters, L. E., Anandakrishnan, S., Alley, R. B., and Voigt, D. E.: Seismic attenuation in glacial ice: A proxy for englacial temperature, J. Geophys. Res.-Earth, 117, F02008, https://doi.org/10.1029/2011JF002201, 2012.

Robin, G. de Q., Swithinbank, C., and Smith, B. M. E.: Radio echo exploration of the Antarctic ice sheet, in: International Symposium on Antarctic Glaciological Exploration (ISAGE), edited by: Gow, A. J., Keeler, C., Langway, C. C., Weeks, W. F., International Association of Scientific Hydrology, Hanover, New Hampshire, 3-7 September 1968, Gentbrugge, IASH Publication, 86, 97-115, 1970.

Rogozhina, I., Petrunin, A. G., Vaughan, A. P. M., Steinberger, B., Johnson, J. V., Kaban, M. K., Calov, R., Rickers, F., Thomas, M., and Koulakov, I.: Melting at the base of the Greenland ice sheet explained by Iceland hotspot history, Nat. Geosci., 9, 366-369, https://doi.org/10.1038/ngeo2689, 2016.

Rutishauser, A., Blankenship, D. D., Sharp, M., Skidmore, M. L., Greenbaum, J. S., Grima, C., Schroeder, D. M., Dowdeswell, J. A., and Young, D. A.: Discovery of a hypersaline subglacial lake complex beneath Devon Ice Cap, Canadian Arctic, Sci. Adv., 4, eaar4353, https://doi.org/10.1126/sciadv.aar4353, 2018. 
Schmerr, N., Maguire, R., Pettit, E., Riverman, K., Gardner, C., DellaGiustina, D., Avenson, B., Wagner, N., Marusiak, A., Habib, N., Broadbeck, J., Bray, V., Bailey, S., Carr, C., Dahl, P., and Weber, R.: Northwest Greenland Active Source Seismic Experiment [data set], Digital Repository at the University of Maryland, https://doi.org/10.13016/yy2o-nhua, 2021.

Shepherd, A., Ivins, E., Rignot, E., Smith, B., van den Broeke, M., Velicogna, I., Whitehouse, P., Briggs, K., Joughin, I., Krinner, G., Nowicki, S., Payne, T., Scambos, T., Schlegel, N., Geruo, A., Agosta, C., Ahlstrøm, A., Babonis, G., Barletta, V., Bjørk A., Blazquez, A., Bonin, J., Colgan, W., Csatho, B., Cullather, R., Engdahl, M. E., Felikson, D., Fettweis, X., Forsberg, R., Hogg, A., Gallee, H., Gardner, A., Gilbert, L., Gourmelen, N., Groh, A., Gunter, B., Hanna, E., Harig, C., Helm, V., Horvath, A., Horwath, M., Khan, S., Kjeldsen, K. K., Konrad, H., Langen, P., Lecavalier, B., Loomis, B., Luthcke, S., McMillan, M., Melini, D., Mernild, S., Mohajerani, Y., Moore, P., Mottram, R., Mouginot, J., Moyano, G., Muir, A., Nagler, T., Nield, G., Nilsson, J., Noël, B., Otosaka, I., Pattle, M. E., Peltier, W. R., Pie, N., Rietbroek, R., Rott, H., Sandberg-Sørensen, L., Sasgen, I., Save, H., Scheuchl, B., Schrama, E., Schröder, L., Seo, K.-W., Simonsen, S., Slater, T., Spada, G., Sutterley, T., Talpe, M., Tarasov, L., van de Berg, W. J., van der Wal, W., van Wessem, M., Vishwakarma, B. D., Wiese, D., Wilton, D., Wagner, T., Wouters, B., and Wuite, J.: Mass balance of the Antarctic Ice Sheet from 1992 to 2018, Nature, 558, 219-222, https://doi.org/10.1038/s41586019-1855-2, 2018.

Siegert, M., Dowdeswell, J., Gorman, M., and McIntyre, N.: An inventory of Antarctic sub-glacial lakes, Antarc. Sci., 8, 281-286, https://doi.org/10.1017/S0954102096000405, 1996.

Siegfried, M. R. and Fricker, H. A.: Thirteen years of subglacial lake activity in Antarctica from multi-mission satellite altimetry, Ann. Glaciol., 59, 42-55, https://doi.org/10.1017/aog.2017.36, 2018.

Siegfried, M. R., Fricker, H. A., Carter, S. P., and Tulaczyk, S.: Episodic ice velocity fluctuations triggered by a subglacial flood in West Antarctica, Geophys. Res. Lett., 43, 2640-2648, https://doi.org/10.1002/2016GL067758, 2016.

Smith, A. M., Woodward, J., Ross, N., Bentley, M. J., Hodgson, D. A., Siegert, M. J., and King, E. C.: Evidence for the long-term sedimentary environment in an Antarctic subglacial lake, Earth Planet. Sci. Lett., 504, 139-151, https://doi.org/10.1016/j.epsl.2018.10.011, 2018.
Smith, B. E., Fricker, H. A., Joughin, I. R., and Tulaczyk, S.: An inventory of active subglacial lakes in Antarctica detected by ICESat (2003-2008), J. Glaciol., 55, 573-595, https://doi.org/10.3189/002214309789470879, 2009.

Stearns, L. A., Smith, B. E., and Hamilton, G. S.: Increased flow speed on a large East Antarctic outlet glacier caused by subglacial floods, Nat. Geosci., 1, 827, https://doi.org/10.1038/ngeo356, 2008.

Tromp, J., Komatitsch, D., and Liu, Q.: Spectral-element and adjoint methods in seismology, Commun. Comput. Phys., 3, 1-32, 2008.

Tulaczyk, S. M. and Foley, N. T.: The role of electrical conductivity in radar wave reflection from glacier beds, The Cryosphere, 14, 4495-4506, https://doi.org/10.5194/tc-14-4495-2020, 2020.

Vick-Majors, T. J., Mitchell, A. C., Achberger, A. M., Christner, B. C., Dore, J. E., Michaud, A. B., Mikucki, J. A., Purcell, A. M., Skidmore, M. L., and Priscu, J. C.: Physiological ecology of microorganisms in subglacial Lake Whillans, Front. Microbiol., 7, 1705, https://doi.org/10.3389/fmicb.2016.01705, 2016.

Welch, B. C. and Jacobel, R. W.: Analysis of deep-penetrating radar surveys of West Antarctica, US-ITASE 2001, Geophys. Res. Lett., 30, 1444, https://doi.org/10.1029/2003GL017210, 2003.

Willis, M., Herried, B., Bevis, M., and Bell, R.: Recharge of a subglacial lake by surface meltwater in northeast Greenland, Nature, 518, 223-227, https://doi.org/10.1038/nature14116, 2015.

Woodward, J., Smith, A. M., Ross, N., Thoma, M., Corr, H., King, E. C., King, M., Grosfeld, K., Tranter, M., and Siegert, M.: Location for direct access to subglacial Lake Ellsworth: An assessment of geophysical data and modeling, Geophys. Res. Lett., 37, L11501, https://doi.org/10.1029/2010GL042884, 2010.

Wright, A. and Siegert, M.: A fourth inventory of Antarctic subglacial lakes, Antarct. Sci., 24, 659-664, https://doi.org/10.1017/S095410201200048X, 2012.

Young, D. A., Schroeder, D. M., Blankenship, D. D., Kempf, S. D., and Quartini, E.: The distribution of basal water between Antarctic subglacial lakes from radar sounding, Philos. T. Roy. Soc. A., 374, 20140297, https://doi.org/10.1098/rsta.2014.0297, 2016. 